\title{
Fungal Species Composition in Maize Stalks in Relation to European Corn Borer Injury and Transgenic Insect Protection
}

\author{
E. W. Gatch and G. P. Munkvold, Department of Plant Pathology, Iowa State University, Ames 50011
}

\begin{abstract}
Gatch, E. W., and Munkvold, G. P. 2002. Fungal species composition in maize stalks in relation to European corn borer injury and transgenic insect protection. Plant Dis. 86:1156-1162.

The maize stalk rot complex is comprised of several fungal pathogens, including Gibberella zeae, Colletotrichum graminicola, Stenocarpella maydis, and several members of the genus Fusarium. The European corn borer (ECB) (Ostrinia nubilalis) can contribute to stalk rot development by creating entry wounds and by serving as a vector of some stalk rot pathogens, particularly Fusarium verticillioides. Transgenic insect protection of maize hybrids with insecticidal proteins derived from Bacillus thuringiensis greatly reduces ECB injury and may therefore alter the species composition and diversity of the stalk rot complex. Field experiments were conducted in 1998, 1999, and 2000 to compare the species composition and diversity of fungi infecting stalks of $\mathrm{Bt}$ and non-Bt maize hybrids. Hybrids representing five $\mathrm{Bt}$ types (or "events") and their near-isogenic non-Bt counterparts were subjected to manual and natural infestations with ECB larvae. Stalk tissue samples were cultured to determine fungal species composition. At least one species was isolated from nearly every stalk and from both diseased and symptomless tissues. G. zeae was the most common species in 1998 and 1999, but $C$. graminicola was most common in 2000. The mean proportions of stalks infected with $F$. verticillioides, $F$. proliferatum, and $F$. subglutinans were significantly lower in Bt hybrids than in non-Bt hybrids in 2 of the 3 years. Conversely, the mean proportion of stalks infected with $G$. zeae was higher in some Bt hybrids than their non-Bt counterparts in two of the three years. $F$. verticillioides was more likely to be isolated from ECB-injured tissue, whereas G. zeae and $C$. graminicola were more likely to be isolated from tissue not associated with ECB injury. The overall species diversity of the stalk rot complex was lower in some Bt hybrids compared with their non-Bt counterparts in 1998 and 1999. ECB activity appeared to alter fungal species composition in stalks, reflecting the association between ECB injury and specific stalk rot pathogens, particularly F. verticillioides. The species composition of fungi infecting stalks of $\mathrm{Bt}$ hybrids differed from that of non-Bt hybrids, but the implications of this result are not yet clear.
\end{abstract}

Additional keywords: corn, GMO, Zea mays

Numerous fungi have been implicated in stalk rot of maize, a disease of worldwide importance whose effects include reduced yields, premature death of plants, and lodged stalks (15). The predominant members of the stalk rot complex in the United States are Gibberella zeae (Schwein.) Petch, Colletotrichum graminicola (Ces.) G. W. Wils., Stenocarpella maydis (Berk.) Sutton, and members of the genus Fusarium, including $F$. verticillioides (Sacc.) Nirenberg, F. proliferatum (T. Matsushima)

Corresponding author: G. P. Munkvold E-mail: munkvold@iastate.edu

This is Journal Paper No. J-19764 of the Iowa Agriculture and Home Economics Experiment Station, Ames, IA, Project No. 3549, supported by Hatch Act and State of Iowa funds. This work was partially supported by grants from the USDA North Central IPM Grant Program, the Leopold Center for Sustainable Agriculture, and Syngenta Seeds, Inc.

Accepted for publication 3 June 2002.

Publication no. D-2002-0815-03R

(c) 2002 The American Phytopathological Society
Nirenberg, and F. subglutinans (Wollenweb. \& Reinking) P. E. Nelson, T. A. Toussoun, and Marasas (17,30). Bipolaris zeicola (G. L. Stout) Shoemaker frequently is isolated from stalks but is considered a minor stalk rot pathogen (30).

Although many of these pathogens occur simultaneously in maize plants, a core complex of several dominant pathogens often is associated with stalk rot in a given region $(11,16,35)$. The relative prevalence of species in this complex, as well as the overall species diversity, can change both within the growing season and gradually over time as new cultural practices and hybrids are introduced, more virulent biotypes of the pathogens appear or disappear, and weather patterns change $(4,16,18,34)$. The predominance of $S$. maydis, for example, has fluctuated greatly over the past several decades, while $C$. graminicola has steadily increased in importance $(14,16)$.

The complex of fungal pathogens found in maize stalks resembles a sophisticated ecological community in many ways. There is evidence that competition occurs among stalk rot pathogens, particularly between $\mathrm{G}$. zeae and Fusarium spp. $(18,19,24)$. Interactions among competing fungi, insect pests, and maize stalks result in distinct mycofloral communities whose composition changes with the plant growth stage and seasonal weather fluctuations, approximating a kind of ecological succession (39).

These shifts in species composition can have implications for the type and severity of the resulting stalk rot, because stalk rot pathogens are known to vary in pathogenicity. C. graminicola and G. zeae generally are believed to cause a more severe decay than other species $(11,18)$. In addition to this interspecific variation, strains within species vary in their ability to cause stalk rot $(11,38)$. There are conflicting reports of the pathogenicity of $F$. verticillioides in maize stalk tissue because this fungus is associated with both stalk rot

Table 1. Maize hybrid representatives of five Bt transformation types (events) and their nearisogenic, non-Bt counterparts used in field experiments conducted near Ames, IA in 1998, 1999, and 2000

\begin{tabular}{llll}
\hline Bt event & \multicolumn{1}{c}{$\mathbf{1 9 9 8}$} & \multicolumn{1}{c}{$\mathbf{1 9 9 9}$} & \multicolumn{1}{c}{$\mathbf{2 0 0 0}$} \\
\hline 176 (KnockOut) & NK (Ciba) MAX21 & NK (Ciba) MAX21 & NK (Ciba) MAX454 \\
Non-Bt & NK (Ciba) 4349 & NK (Ciba) 4394 & NK (Ciba) 4494 \\
Bt11 (Yieldgard) ${ }^{\mathrm{b}}$ & NK 4640Bt & NK 7070Bt & NK 7070Bt \\
Non-Bt & NK 4640 & NK 7070 & NK 7070 \\
MON810 (Yieldgard) & Pioneer 34R06 & Pioneer 34R06 & Pioneer 34R06 \\
Non-Bt & Pioneer 3489 & Pioneer 3489 & Pioneer 3489 \\
DBT418 (BtXtra) ${ }^{\mathrm{d}}$ & DK 566Bt & DK 595Bt & DK 595Bt \\
Non-Bt & DK 566 & DK 595 & DK 595 \\
CBH351 (StarLink) & Garst 8600Bt & Garst 8539 BLT & Garst 8539 BLT \\
Non-Bt & Garst 8600 & Garst 8539 IT & Garst 8539 IT \\
\hline
\end{tabular}

a Ciba Seeds, Greensboro, NC.

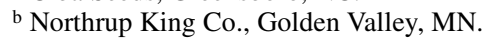

${ }^{c}$ Monsanto Co., St. Louis, MO.

${ }^{\mathrm{d}}$ DeKalb Plant Genetics, DeKalb, IL.

e Garst Seeds, Inc., Slater, IA. 
and symptomless infection of stalk tissue $(11,25,38)$.

Stalk rot fungi are aided in the colonization and decay of maize stalks by environmental stresses that heighten the plant's susceptibility to infection, particularly following anthesis when carbohydrate shortages can occur (9). Injury due to the feeding of the European corn borer (ECB), Ostrinia nubilalis Hübner, can significantly stress maize plants and encourage stalk rot development in several ways $(6,7,15)$. By tunneling into stalk tissue, larvae create entry points for fungal pathogens. Extensive tunneling compromises maize plants physiologically and can hasten the development of stalk rot symptoms. Finally, ECB larvae can serve as vectors of some stalk rot fungi, particularly $F$. verticillioides (31).

Because of the association between ECB injury and certain stalk rot pathogens, measures taken to control ECB infestations could affect the species composition and diversity of the stalk rot complex. ECB tunneling is only one of several infection pathways for stalk rot pathogens. Given our knowledge of fungus-insect dynamics, it is possible that the fungal community in ECB-injured stalk tissue differs from other rotted tissue in both composition and overall diversity. The concept of species diversity has numerous definitions and applications in ecological investigations. Several mathematical indices have been developed to gauge species diversity $(8,12,29)$, and some have been used in plant pathology research. The Simpson diversity index (29) is suitable for assessing both species richness (total number) and species evenness (relative abundance).

In the past, ECB management tools were limited to foliar applications of insecticides, which are frequently ineffective due to difficulty in scouting and timing treatments to control the larvae before they bore into plants. In response to the need for improved ECB control, transgenic $\mathrm{Bt}$ hybrids were developed. Bt hybrids are created by the insertion into the maize genome of a gene sequence derived from the bacterium Bacillus thuringiensis that codes for production of a lepidopteranspecific insecticidal protein $(5,13)$. Six different transformation types, defined by the specific Bt protein and the promoter sequence used, have been registered by the U.S. Environmental Protection Agency for commercial use.

Bt hybrids have been widely adopted by U.S. farmers since their introduction in 1996 for the protection they provide against ECB injury. Area planted with Bt hybrids increased from $1.4 \%$ of all maize in 1996 to $25.9 \%$ in 1999; farmers planted 22\% Bt hybrids in 2002 (33). As controversy over the use of these and other transgenic crops has escalated, so has the need for further investigation of how Bt hybrids will influence the com-
Table 2. $P$ values for the effects of brand, $\mathrm{Bt}$ transformation $(\mathrm{Bt})$, manual or natural European corn borer infestation (Trt), and interactions among these variables on the incidence of selected fungal pathogens in stalks of maize from field experiments conducted near Ames, IA in 1998, 1999, and 2000 ${ }^{\mathrm{a}}$

\begin{tabular}{|c|c|c|c|c|c|}
\hline Year & $\begin{array}{c}\text { Gibberella } \\
\text { zeae }\end{array}$ & $\begin{array}{c}\text { Fusarium } \\
\text { verticillioides }\end{array}$ & $\begin{array}{c}\text { Fusarium } \\
\text { proliferatum }\end{array}$ & $\begin{array}{c}\text { Fusarium } \\
\text { subglutinans }\end{array}$ & $\begin{array}{c}\text { Colletotrichum } \\
\text { graminicola }\end{array}$ \\
\hline \multicolumn{6}{|l|}{1998} \\
\hline Brand & $<0.01$ & 0.23 & 0.18 & 0.44 & $<0.01$ \\
\hline $\mathrm{Bt}$ & 0.48 & $<0.01$ & $<0.01$ & 0.55 & 0.58 \\
\hline Trt & $<0.01$ & $<0.01$ & 0.01 & 0.88 & 0.86 \\
\hline Brand $\mathrm{x}$ Bt & $<0.01$ & 0.98 & 0.17 & 0.51 & 0.96 \\
\hline Brand $\mathrm{x}$ Trt & 0.07 & 0.67 & 0.21 & 0.47 & 0.22 \\
\hline Trt $x \mathrm{Bt}$ & 0.15 & 0.03 & 0.90 & 0.24 & 0.73 \\
\hline \multicolumn{6}{|l|}{1999} \\
\hline Brand & $<0.01$ & 0.46 & 0.97 & 0.18 & 0.02 \\
\hline $\mathrm{Bt}$ & $<0.01$ & 0.38 & 0.41 & 0.04 & 0.78 \\
\hline Trt & 0.01 & $<0.01$ & 0.06 & 0.05 & 0.75 \\
\hline Brand $\mathrm{x} B t$ & 0.20 & 0.65 & 0.60 & 0.11 & 0.10 \\
\hline Brand $\mathrm{x}$ Trt & 0.09 & 0.85 & 0.99 & 0.33 & 0.49 \\
\hline Trt $x \mathrm{Bt}$ & 0.75 & 0.06 & 0.32 & 0.13 & 0.94 \\
\hline \multicolumn{6}{|l|}{2000} \\
\hline Brand & $<0.01$ & 0.21 & 0.20 & 0.02 & $<0.01$ \\
\hline $\mathrm{Bt}$ & $<0.01$ & $<0.01$ & 0.20 & $<0.01$ & 0.18 \\
\hline Trt & 0.83 & $<0.01$ & 0.66 & 0.41 & 0.89 \\
\hline Brand X Bt & $<0.01$ & 0.34 & 0.68 & 0.90 & 0.25 \\
\hline Brand X Trt & 0.96 & 0.30 & 0.62 & 0.21 & 0.33 \\
\hline Trt X Bt & 0.40 & 0.89 & 0.03 & 0.62 & $<0.01$ \\
\hline
\end{tabular}

a Brand is the company of origin of each hybrid. Each brand represents a different Bt type. Manual infestation consisted of applying 50 neonatal larvae to the whorl (at growth stage V8 to V9) or earleaf axil (at stage R1) of each plant.

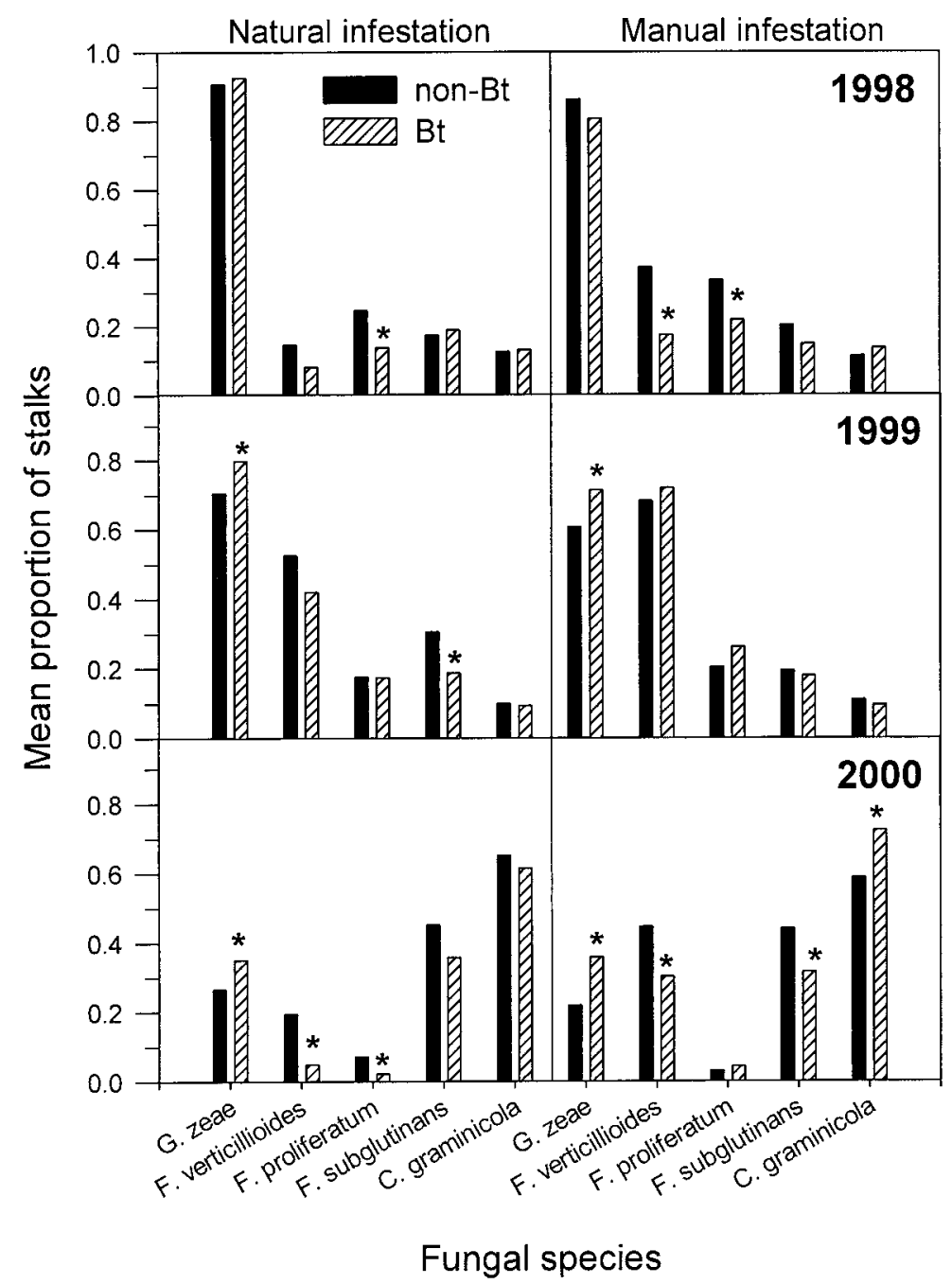

Fig. 1. Mean proportions of stalks infected with selected stalk rot pathogens in Bt and non-Bt maize hybrids in field experiments in central Iowa in 1998, 1999, and 2000. G. = Gibberella, F. $=$ Fusarium, and C. = Colletotrichum. Values are based on eight replicates of four stalks each. Asterisks indicate significant differences $(P \leq 0.05)$ between $\mathrm{Bt}$ and non-Bt counterparts, according to planned orthogonal contrasts. 
plex interactions among insect pests, diseases, and the environment. Previous studies examining the potential role of $\mathrm{Bt}$ hybrids in maize stalk rot management have not had consistent results, although there is some evidence that certain $\mathrm{Bt}$ transformation types may be more effective than others in reducing stalk rot $(3,10,20,26)$. These experiments were based on visual assessments of stalk rot symptoms; to date, there have been no attempts to examine the effects of $\mathrm{Bt}$ hybrids on the fungal communities responsible for stalk decay. The objectives of this study were to assess the influence of ECB injury on fungal species composition in maize stalks, and to determine whether the species composition and diversity of the stalk rot complex are altered by the use of Bt hybrids.

\section{MATERIALS AND METHODS}

Field experiments were conducted in 1998 through 2000 in the vicinity of Ames, IA. Each year, five Bt hybrids and their near-isogenic non-Bt counterparts (Table
1) were evaluated in field plots arranged in a randomized complete block design with eight replications. Fields were located at the Iowa State University Johnson farm (Story County) in 1998, Woodruff farm (Boone County) in 1999, and the Agronomy and Engineering Research Farm (Boone County) in 2000. All fields were in a maize-soybean rotation and were field cultivated prior to planting between midand late May. Standard fertilization and weed management practices were applied in all fields. Plots consisted of four rows $5.33 \mathrm{~m}$ in length planted at a density of 123,000 seeds/ha and thinned to approximately 69,000 plants/ha, with plants spaced 15 to $20 \mathrm{~cm}$ apart to standardize competition with neighboring plants. Each plot was subjected to one of two treatments: (i) manual infestation, consisting of two ECB infestations, one at growth stage V8 to V9 (mid-whorl) and one at growth stage R1 (silk stage) (27); and (ii) natural infestation (no manual infestations). Larvae for the manual infestations were reared at the United States

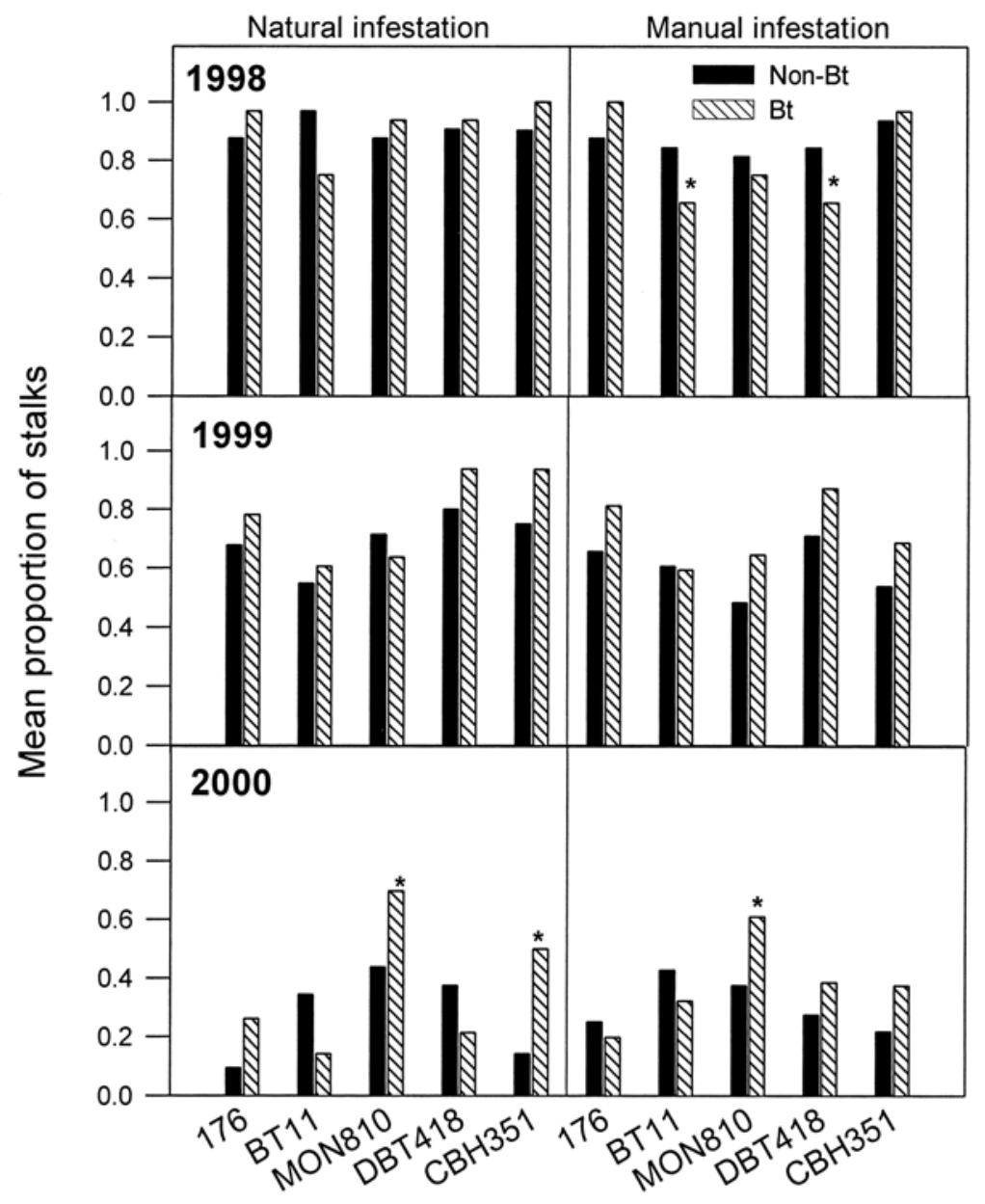

\section{Bt transformation types and non-Bt isolines}

Fig. 2. Mean proportions of stalks infected with Gibberella zeae in tissue samples collected from five Bt maize hybrids and their non-Bt counterparts in field experiments in central Iowa 1998, 1999, and 2000. Each Bt transformation type is represented by a different hybrid brand. Values are based on eight replicates of four stalks each. Asterisks indicate significant differences $(P \leq 0.05)$ between $\mathrm{Bt}$ and non-Bt counterparts, according to planned orthogonal contrasts.

Department of Agriculture-Agricultural Research Service Corn Insects Laboratory in Ames and applied to plants using an applicator that delivered approximately 50 neonatal larvae mixed with ground maize cobs to the whorl at V8 to V9 and to the axil of the ear shank at R1 (21). Each of the infestations was applied twice within a 1-week period. No inoculation of stalk rot pathogens was made, because these fungi are present naturally in crop residue and soil.

Stalks were sampled at physiological maturity, as indicated by formation of a black layer on the kernel. Sampling consisted of systematic selection of four stalks (every fifth or sixth stalk) from an inner row of each four-row plot. Stalks were cut off at the base with a pruning shears, trimmed back four nodes above the ear node, and split longitudinally.

Tissue cross sections approximately 5 $\mathrm{cm}$ in length were excised aseptically from each stalk. If disintegrated pith was observed, the decayed portion of the stalk was sampled. If no pith disintegration was present, a section of discolored tissue was sampled. In the absence of either pith disintegration or stalk discoloration, a section of healthy tissue was sampled. If ECB injury had occurred, tissue associated with the injury also was sampled and classified as disintegrated, discolored, or symptomless. Tissue samples were subsequently divided into four pieces, which were surface disinfested for $1 \mathrm{~min}$ in a $0.5 \% \mathrm{NaOCl}$ solution, placed onto potato dextrose agar (Difco, Becton Dickinson and Co., Sparks, MD) and incubated in the dark at $25^{\circ} \mathrm{C}$ until recognizable fungal colonies were formed (approximately 4 days). The colonies were transferred to carnation leaf agar for identification. Fusarium spp. were identified based on morphology, as described by Nelson et al (22) or Nirenberg (23). Non-Fusarium stalk rot pathogens such as C. graminicola, Bipolaris zeicola, and $S$. maydis also were identified by morphology $(1,32)$. The fungi detected can all grow rapidly on potato dextrose agar; however, slower-growing fungi may have escaped detection.

The SAS statistical package (Statistical Analysis System; SAS Institute, Inc., Cary, NC) was used for all analyses. Analyses of variance were conducted on the mean proportions of stalk tissue samples per plot from which a given species was isolated. Four-way analysis of variance was carried out to determine the main effects of hybrid brand (company of origin of each hybrid), presence of $\mathrm{Bt}$ proteins $(\mathrm{Bt})$, manual or natural infestation (treatment), and replicate block, as well as interactions among these variables. Each hybrid brand contained a different $\mathrm{Bt}$ type; therefore, the brand by $\mathrm{Bt}$ interaction was interpreted to represent differential effects among $\mathrm{Bt}$ types. Analyses of variance also were conducted to assess whether mean proportions 
of stalks infected by each fungal species differed significantly among tissues that were disintegrated, discolored, or symptomless, and between tissues that were or were not associated with ECB injury. The Simpson Diversity Index, which is a measure of both species evenness (relative abundance of each species) and, to a lesser extent, species richness (total number of species), was calculated for Bt transformation types and their non-Bt counterparts $(8,12,29)$. Mean separation was performed using orthogonal contrast analysis or Duncan's multiple range test.

\section{RESULTS}

Stalk rot pathogens were isolated from nearly every stalk sampled. The pathogens isolated in highest proportions were $G$. zeae, $F$. verticillioides, $F$. proliferatum, $F$. subglutinans, and C. graminicola. G. zeae was the most common species in 1998 and 1999, isolated from 87 and $70 \%$ of sampled stalks, respectively. C. graminicola was the most common in 2000, isolated from $64 \%$ of sampled stalks. Less prevalent fungi recovered included $F$. sporotrichioides (3-year mean, 16\%), F. semitectum $(8 \%), F$. acuminatum (10\%), F. equiseti (8\%), $S$. maydis (5\%), and $B$. zeicola $(14 \%)$.

The composition of fungal stalk rot species differed among hybrid brands, between $\mathrm{Bt}$ and non-Bt hybrids, between manual and natural ECB infestation, and among years (Table 2). The mean proportion of stalks infected with $F$. verticillioides was significantly lower in Bt hybrids than in non-Bt hybrids in 1998 (manual infestation) and 2000 (Fig. 1). Similarly, the proportions of stalks infected with $F$. proliferatum and $F$. subglutinans were significantly lower in $\mathrm{Bt}$ hybrids compared with non-Bt hybrids in 2 of the 3 years, depending on the infestation treatment (Fig. 1). In 1999 and 2000, the proportions of stalks infected with $G$. zeae were significantly higher in $\mathrm{Bt}$ hybrids compared with non-Bt hybrids (Fig. 1), but these differences were dependent upon hybrid brand (and therefore Bt type) in 2000 (Fig. 2). The proportion of stalks infected with $C$. graminicola was significantly higher in Bt hybrids than in non-Bt hybrids in 2000 (manual infestation; Fig. 1).

Comparisons of species composition among three types of stalk tissue (disintegrated, discolored, and symptomless) were carried out in 1999 and 2000 (Fig. 3). Disintegrated tissue had significantly higher proportions of most stalk rot pathogens than other tissue types in both years. There were significantly higher proportions of $G$. zeae in disintegrated stalk tissue compared with discolored tissue in both 1999 and 2000. Proportions of $C$. graminicola in disintegrated and discolored tissue were significantly higher compared with symptomless tissue in 2000. Also in 2000, the proportions of $F$. subglutinans and $F$. acuminatum in disintegrated tissue were significantly higher compared with symptomless tissue. In 1999, the proportions of $F$. verticillioides and $F$. subgluti- nans were significantly higher in disintegrated compared with discolored tissue, and were higher for $F$. verticillioides in discolored tissue compared with symptomless tissue.

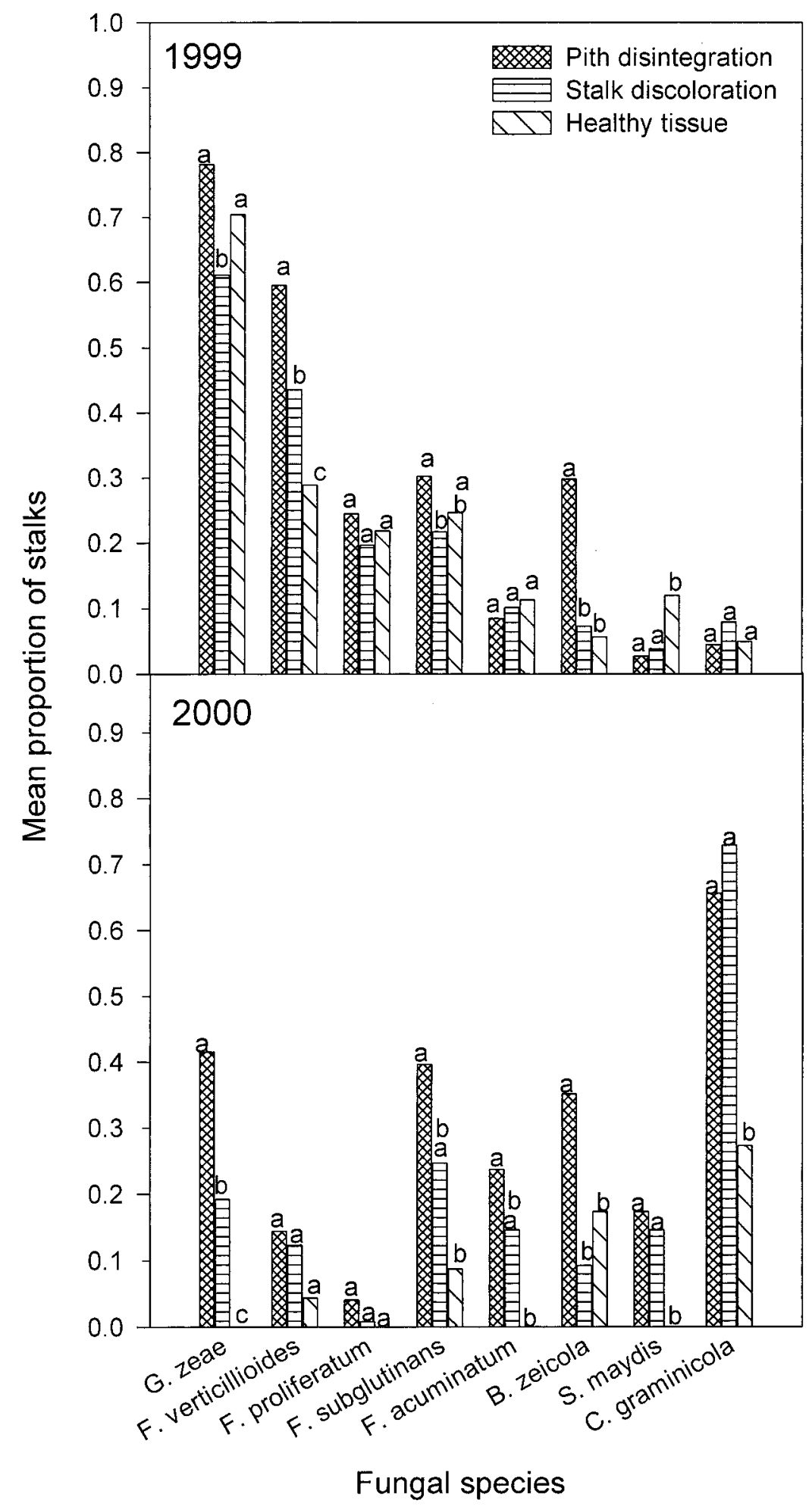

Fig. 3. Mean proportions of maize stalks infected with selected stalk rot pathogens in tissue samples showing either discoloration, pith disintegration, or lack of symptoms (healthy) in field experiments in central Iowa in 1999 and 2000. G. = Gibberella, F. = Fusarium, B. = Bipolaris, $S$. = Stenocarpella, and $C .=$ Colletotrichum. Values are based on eight replicates of four stalks each. Within each species, bars with the same letter indicate values that are significantly different $(P \leq$ $0.05)$, according to Duncan's multiple range test. 
Species composition of the stalk rot complex also was influenced by whether or not the stalk tissue sample was associated with ECB injury, a distinction recorded in 1999 and 2000 (Fig. 4). The proportion of stalks infected with $F$. verticillioides was higher in ECB-associated stalk rot compared with stalk rot not associated with ECB injury in both 1999 and 2000, whereas the proportion of $G$. zeae was

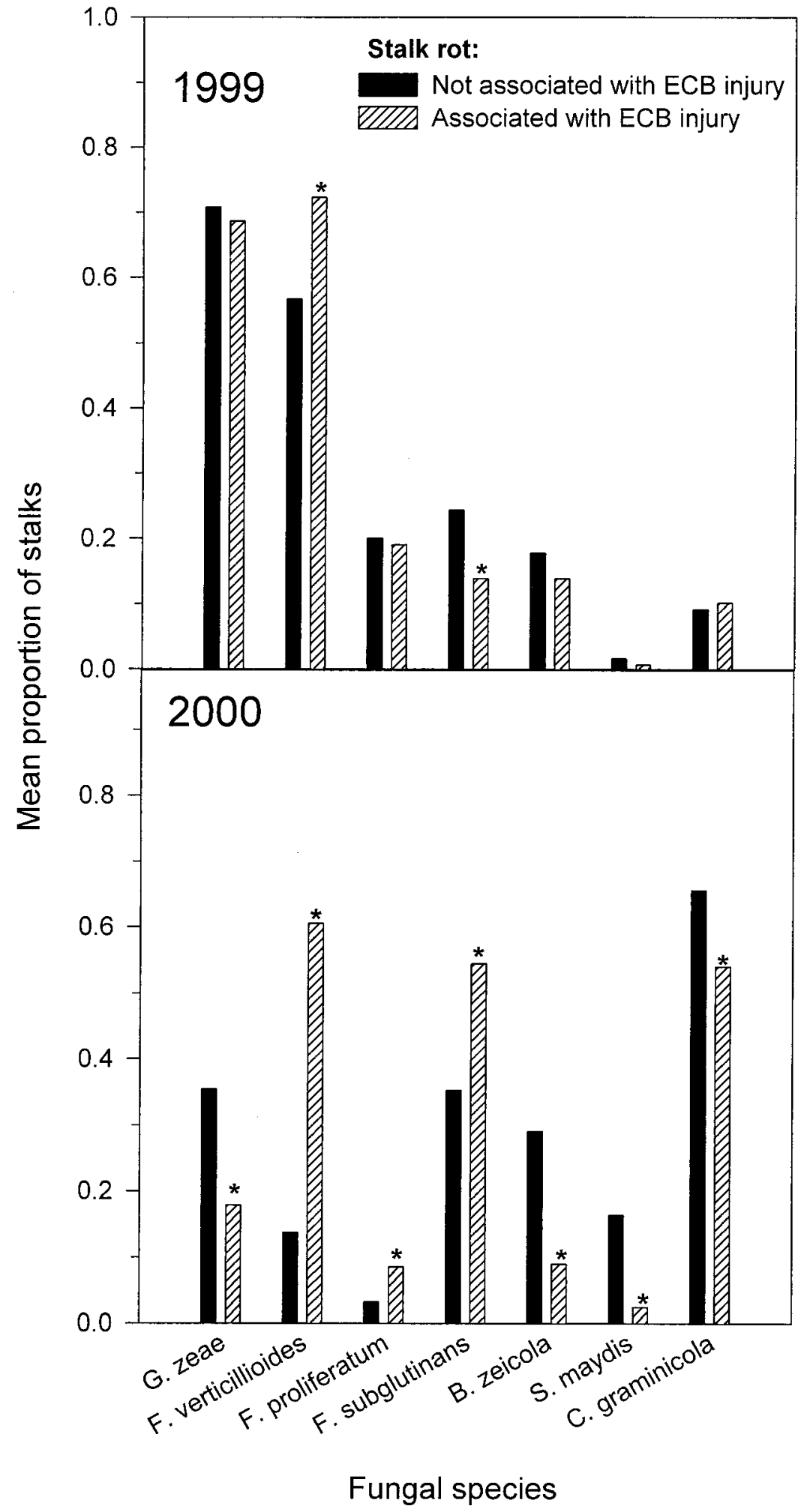

Fig. 4. Mean proportions of maize stalks infected with selected stalk rot pathogens in stalk rot not associated with ECB injury and stalk rot associated with ECB injury in field experiments in central Iowa in 1998, 1999, and 2000. G. = Gibberella, $F .=$ Fusarium, B. = Bipolaris, S. = Stenocarpella, and $C .=$ Colletotrichum . Values are based on eight replicates of four stalks each. Asterisks indicate significant differences $(P \leq 0.05)$ between Bt and non-Bt counterparts, according to planned orthogonal contrasts. lower in ECB-associated stalk rot in 2000. Proportions of $F$. proliferatum and $F$ subglutinans were higher in ECBassociated stalk rot compared with nonECB-associated stalk rot in 2000, whereas the proportion of $F$. subglutinans was lower in ECB-associated stalk rot in 1999. Proportions of B. zeicola, S. maydis, and C. graminicola were lower in ECB-associated rot in 2000.

Certain Bt transformation types (176 and $\mathrm{CBH}$ 351) had significantly reduced species diversity indices compared with their non-Bt counterparts, depending on the year (Table 3).

\section{DISCUSSION}

The management of maize stalk rots is complicated by the little-understood dynamics of the fungal populations responsible for stalk decay. Previous work on the role of environmental stresses such as leaf disease, overpopulation, and insect injury in stalk rot development have tended to focus on visual symptoms of decay, with little investigation of how these factors affect the complex fungal communities found in both diseased and healthy stalk tissue. We would be remiss to continue overlooking these fluctuations in stalk rot species composition, because stalk rot pathogens differ in dispersal mechanisms, environmental preferences, aggressiveness, mycotoxin production, resistance to plant defenses, and other traits of epidemiological consequence $(4,16,35,37)$.

Bt hybrids provide a unique tool for examining the species composition of the stalk rot complex in relation to ECB injury, one of the stresses known to contribute to stalk rot development. Studies demonstrating a vector relationship between ECB larvae and several stalk rot pathogens provided a rationale for our hypothesis that $\mathrm{Bt}$ hybrids might have reduced proportions of these pathogens in their stalk tissue (31). The results of the present study substantiate this hypothesis with respect to some species, because the relative proportions of $F$. verticillioides, one of the species transmitted by ECB larvae, were significantly reduced in $\mathrm{Bt}$ hybrids compared to non-Bt hybrids in 2 out of 3 years. A similar but less-pronounced pattern was observed in the reduced proportion of Bt stalks infected with $F$. proliferatum and $F$. subglutinans, species whose vector relationship with ECB larvae is suspected but not confirmed (31). These reductions in the occurrence of Fusarium spp. in Bt hybrids may account for the decreased species diversity observed in some $\mathrm{Bt}$ hybrids compared with their non-Bt counterparts.

A comparison of the fungal complex isolated from rotted stalk tissue both with and without ECB injury proved useful in the interpretation of species composition variation between $\mathrm{Bt}$ and non-Bt hybrids. In each of the 2 years this comparison was made, the proportion of stalks infected 
with $F$. verticillioides was significantly higher in the ECB injury-associated stalk rot than stalk rot not associated with ECB injury. This is consistent with observations of Koehler (16), who reported that $F$. verticillioides (reported as $F$. moniliforme) was the most common fungus recovered from stalk injured by ECB, and that infections of S. maydis (reported as Diplodia zeae) and G. zeae were not increased by stalk injury. This result reflects the established vector relationship between $F$. verticillioides and ECB larvae (31) and may explain why Bt hybrids, which have greatly reduced levels of ECB injury, also had significantly lower proportions of $F$. verticillioides than nonBt hybrids in 2 out of 3 years. It also is possible that ECB injury predisposed the plants specifically to $F$. verticillioides by providing entry wounds $(6,7)$ and physiological stress associated with stalk injury (9). Alternatively, it is possible that stalks infected by $F$. verticillioides were more attractive to ECB adults or that ECB larvae were more successful in stalks already infected by $F$. verticillioides. In West Africa, maize stalks inoculated with $F$. verticillioides had a higher incidence of infestation by Eldana saccharina, an insect pest in the same family (Pyralidae) as ECB (28). The authors proposed several explanations, including the production of volatiles by the fungus, which have been shown to attract some insects (2).

The significantly higher proportion of stalks infected with G. zeae in Bt hybrids versus non-Bt hybrids in 1999 and 2000 also may be explained by the ECB-associated versus non-ECB-associated stalk rot comparison. Stalk rot that was not associated with ECB injury (the type usually found in Bt hybrids) had significantly higher proportions of G. zeae in 2000 than ECB-associated stalk rot. Non-ECBassociated stalk rot also had significantly higher proportions of $S$. maydis, B. zeicola, and C. graminicola in 2000 compared with ECB-associated stalk rot. It should be noted that, in 2000, the effects of Bt transformation on G. zeae were dependent upon hybrid brand and that, in 1998, two $\mathrm{Bt}$ transformation types showed the opposite

Table 3. Values for Simpson Diversity Index for maize stalk tissues sampled from field experiments conducted near Ames, IA, in 1998, 1999, and 2000 ${ }^{\mathrm{a}}$

\begin{tabular}{lllll}
\hline Bt type & & $\mathbf{1 9 9 8}$ & $\mathbf{1 9 9 9}$ & $\mathbf{2 0 0 0}$ \\
\hline 176 & $\mathrm{Bt}$ & 0.67 & 0.81 & 0.77 \\
& Non-Bt & $0.76^{*}$ & 0.85 & 0.81 \\
BT11 & $\mathrm{Bt}$ & 0.82 & 0.85 & 0.80 \\
& Non-Bt & 0.83 & 0.85 & 0.83 \\
MON810 & $\mathrm{Bt}$ & 0.71 & 0.86 & 0.86 \\
& Non-Bt & 0.72 & 0.85 & 0.86 \\
DBT418 & $\mathrm{Bt}$ & 0.72 & 0.81 & 0.86 \\
& Non-Bt & 0.75 & $0.86^{*}$ & 0.83 \\
CBH351 & $\mathrm{Bt}$ & 0.67 & 0.84 & 0.86 \\
& Non-Bt & $0.77^{*}$ & 0.83 & 0.84 \\
\hline
\end{tabular}

a Simpson index $D=1-\left[\sum n_{i}\left(n_{i}-1\right)\right] /[N(N-1)] ; S=$ number of species, $n_{i}=$ number of individuals belonging to species, $N=$ total number of individuals. Values followed by an asterisk are significantly different from non-Bt counterparts at $P \leq 0.05$. pared with their non-Bt counterparts. During the 3 years of our study, there was a pattern of above-average spring rainfall, below-average late-summer rainfall, and above-average late-summer temperatures. The magnitude of these departures from normal differed among seasons, with 2000 having the most extreme conditions. The variable weather among seasons seems to have influenced the results; G. zeae infection apparently was not favored by the very dry late-season conditions in 2000. Overall, the effect of $\mathrm{Bt}$ transformation on G. zeae occurrence in maize stalks was not as clear as the effect on $F$. verticillioides.

Proportions of stalks infected by G. zeae and $C$. graminicola differed among hybrid brands. This probably reflects differences in genotype susceptibility among the hybrids, independent of the presence or absence of $\mathrm{Bt}$ transformation. Each brand also represents a different Bt type; therefore, the significant interaction for $G$. zeae infection in 2000 suggests that the effect of Bt transformation on infection by this fungus depends on the Bt type.

Further research is necessary to explain the increased proportions of $G$. zeae and non-Fusarium stalk rot pathogens in tissue unaffected by ECB injury. It has been speculated, however, that interspecific competition may occur in stalk tissue $(18,36)$. Reduced infection of $\mathrm{Bt}$ maize stalks by $F$. verticillioides may provide an unoccupied niche that can be filled by other pathogens. The results of this project suggest that Fusarium spp. compete with other fungal pathogens in maize stalks, and that the shifts in species composition we observed in $\mathrm{Bt}$ hybrids are a reflection of the effects of ECB on fungal interactions in stalk tissue. The consequences of such a shift in species composition are not yet known.

\section{ACKNOWLEDGMENTS}

We thank J. Shriver for technical assistance in the field and laboratory; C. Martinson and R. Hellmich for advice, technical assistance, and for reviewing the manuscript; and J. Dyer, USDAARS Corn Insects and Crop Genetics Research Unit, for generously supplying European corn borer larvae. effect of lower proportions of G. zeae com-

\section{LITERATURE CITED}

1. Barnett, H. L., and Hunter, B. B. 1998. Illustrated Genera of Imperfect Fungi. American Phytopathological Society Press, St. Paul, MN.

2. Bartelt, R. J., and Wicklow, D. T. 1999. Volatiles from Fusarium verticillioides (Sacc.) Nirenb., and their attractiveness to Nitidulid beetles. J. Agric. Food Chem. 47:2447-2454.

3. Bergstrom, G. C., Davis, P. M., and Waldron, J. K. 1997. Management of anthracnose stalk rot/European corn borer pest complex with transgenic Bt corn hybrids for silage production. Biol. Cult. Tests 12:14.

4. Bergstrom, G. C., and Nicholson, R. L. 1999. The biology of corn anthracnose; knowledge to exploit for improved management. Plant Dis. 83:596-607.

5. Carozzi, N. B., and Koziel, M. G. 1997. Transgenic maize expressing a Bacillus thuringiensis insecticidal protein for control of the European corn borer. Pages 63-74 in: Advances in Insect Control: The Role of Transgenic Plants. N. B. Carozzi and M. G. Koziel, eds. Taylor and Francis, Philadelphia.

6. Chiang, H. C., and Wilcoxson, R. D. 1961 Interactions between the European corn borer and stalk rot in corn. J. Econ. Entomol. 54:850-852.

7. Christensen, J. J., and Schneider, C. L. 1950. European corn borer (Pyrausta nubilalis Hbn.) in relation to shank, stalk, and ear rots of corn. Phytopathology 40:284-291.

8. DeJong, T. M. 1975. A comparison of three diversity indices based on their components of richness and evenness. OIKOS 26:222-227.

9. Dodd, J. L. 1980. The role of plant stresses in development of corn stalk rots. Plant Dis. 64:533-537.

10. Gatch, E. W., Hellmich, R. L., and Munkvold, G. P. 2002. A comparison of maize stalk rot occurrence in Bt and non-Bt hybrids. Plant Dis. 86:1149-1155.

11. Gilbertson, R. L., Brown, W. M., Jr., and Ruppel, E. G. 1985. Prevalence and virulence of Fusarium spp. associated with stalk rot of corn in Colorado. Plant Dis. 69:1065-1068.

12. Groth, J. V., and Roelfs, A. P. 1987. The concept and measurement of phenotypic diversity in Puccinia graminis on wheat. Phytopathology 77:1395-1399.

13. Hofte, H., and Whitley, H. R. 1989. Insecticidal crystal proteins of Bacillus thuringiensis. Microbiol. Rev. 53:242-254.

14. Hooker, A. L., and White, D. G. 1976. Prevalence of corn stalk fungi in Illinois. Plant Dis. Rep. 60:1032-1034.

15. Jarvis, J. L., Clark, R. L., Guthrie, W. D Berry, E. C., and Russell, W. A. 1984. The relationship between second-generation European corn borers and stalk rot fungi in maize hybrids. Maydica 29:247-263.

16. Koehler, B. 1960. Cornstalk rots in Illinois. Univ. Ill. Exp. Stn. Bull. 658.

17. Kommedahl, T., and Windels, C. E. 1981 Root-, stalk-, and ear-infecting Fusarium species on corn in the USA. Pages 94-104 in: Fusarium: Diseases, Biology, and Taxonomy. Pennsylvania State University, University Park.

18. Kommedahl, T., Windels, C. E., and Stucker, R. W. 1979. Occurrence of Fusarium species in roots and stalks of symptomless corn plants during the growing season. Phytopathology 69:961-966.

19. Lipps, P. E., and Deep, I. W. 1991. Influence of tillage and crop rotation on yield, stalk rot, and recovery of Fusarium and Trichoderma spp. on corn. Plant Dis. 75:828-833.

20. Munkvold, G. P. 1998. Disease control with Bt corn? Integr. Crop Manage. Iowa State Univ. Ext. Publ. 480:1-3.

21. Munkvold, G. P., Hellmich, R. L., and Showers, W. B. 1997. Reduced Fusarium ear rot 
and symptomless infection in kernels of maize genetically engineered for European corn borer resistance. Phytopathology 87:1071-1077.

22. Nelson, P. E., Toussoun, T. A., and Marasas, W. F. O. 1983. Fusarium species: an illustrated manual for identification. The Pennsylvania State University Press, University Park.

23. Nirenberg, H. I. 1976. Untersuchunger ber die morphologische und biologische differenzierung in der Fusarium - Sektion Liseola. Mitt. Biol. Bundesant. Land-Fortwirtsch. Berlin-Dahlem 169:1-117.

24. Ocamb, C. M., and Kommedahl, T. 1994. Growth of rhizosphere competent and incompetent Fusarium species from corn on carbon substrates. Phytopathology 84:508-514.

25. Peterson, J. L. 1961. Studies on the prevalence and comparative pathogenicity of fungi associated with corn stalk rot. Plant Dis. Rep. 45:208-210.

26. Reimers, C. I., Clark, T. L., Kamble, S. T., and Foster, J. E. Relationship of European corn borer and stalk rots in $\mathrm{Bt}$ and near-isoline non-Bt maize hybrids in southeastern Nebraska. 1998. Entomol. Soc. Am. North Cent. Branch Meet. Abstr.
27. Ritchie, S. W., Hanway, J. J., and Benson, G. O. 1992. How a corn plant develops. Iowa State Univ. Sci. Technol. Coop. Ext. Serv. Spec. Rep. No. 48.

28. Schultess, F., Cardwell, K. F., and Gounou, S. 2002. The effect of endophytic Fusarium verticillioides on infestation of two maize varieties by lepidopterous stemborers and coleopteran grain feeders. Phytopathology 92:120-128.

29. Simpson, E. H. 1949. Measurement of diversity. Nature 163:688.

30. Smith, D. R., and White, D. G. 1988. Diseases of corn. Pages 687-766 in: Corn and Corn Improvement. American Society of Agronomy, Inc.; Crop Science Society of America, Inc.; and Soil Science Society of America, Inc., Madison, WI.

31. Sobek, E. A., and Munkvold, G. P. 1999. European corn borer (Lepidoptera: Pyralidae) as vectors of Fusarium moniliforme, causing kernel rot and symptomless infection of maize kernels. J. Econ. Entomol. 92:503-509.

32. Sutton, B. C. 1980. The Coelomycetes. Commonwealth Mycological Institute, Kew, UK.

33. United States Department of Agriculture, National Agricultural Statistics Service. 2002.
Acreage. USDA-NASS Report $\mathrm{Cr}$ Pr 2-5. June, 2002.

34. Wheeler, H., Politis, D. J., and Poneleit, C. G. 1974. Pathogenicity, host range, and distribution of Colletotrichum graminicola on corn Phytopathology 64:293-296.

35. White, D. G. 1999. Fungal stalk rots. Pages 38-44 in: Compendium of Corn Diseases. 3rd ed. American Phytopathological Society Press, St. Paul, MN.

36. Windels, C. E., and Kommedahl, T. 1984. Late-season colonization and survival of Fusarium graminearum Group II in cornstalks in Minnesota. Plant Dis. 68:791-793.

37. Windels, C. E., Kommedahl, T., Stienstra, W. C., and Burnes, P. M. 1988. Occurrence of Fusarium species in symptom-free and overwintered cornstalks in northwestern Minnesota. Plant Dis. 72:990-993.

38. Yates, I. E., Bacon, C. W., and Hinton, D. M. 1997. Effects of endophytic infection by Fusarium moniliforme on corn growth and cellular morphology. Plant Dis. 81:723-728.

39. Young, T. R., and Kucharek, T. A. 1977. Succession of fungal communities in roots and stalks of hybrid field corn grown in Florida. Plant Dis. Rep. 61:76-80. 